\title{
The Influence of Fashion Lifestyle, Sales Promotion and Self- image to Impulse Buying Behaviour and Customer Satisfaction
}

\author{
Dewi Mayasari \\ Narotama University \\ Dewimayasari272@gmail.com
}

\begin{abstract}
This study is to analyze the influence of fashion lifestyle, sales promotion, and self image to impulse buying behaviour and customer satisfaction. Type of research is quantitive. The population of this study were 100 students who used the shopee mobile application at Narotama Surabaya University. The analysis technique used is Partial Least Square. Data obtained from questionnaires and tested with SmartPLS 3.0 application. The results of this study indicate that lifestyle fashion, sales promotion, and self image have a positive and significant influence on Impulse buying behavior and customer satisfaction. And impulse buying behavior has a positive and significant effect on customer satisfaction. The limitations of the results of this study cannot be generalized because this research data only comes from one industry. Further research is possible to further explore the roles of other independent variables on impulsive buying behavior and customer satisfaction in the online shop.

Keywords: : Fashion Lifestyle, Sales promotion, Self Image, Impulse Buying Behaviour, Customer Satisfaction.
\end{abstract}

\section{INTRODUCTION}

Customer satisfaction is a feeling of pleasure or disappointment that someone appears after comparing the performance of product results that are thought of the expected performance [1]. In order to be able to survive in the business world, the company must be able to improve its marketing strategy to maintain its customers, companies must meet the needs and desires of customers, for example by providing promotional programs. One special feature of customer satisfaction is those who make regular and repeated purchases. The process towards the level of customer satisfaction begins when the customer evaluates the product or service, services, and certain programs offered by the company so that the customer has specific experience about impulse buying behavior. Another thing that is not less important is the situational factor of the customer's attitude which also influences the conduct of impulse buying behavior so that it is easy to move to competing products or services.

The focus of this research is on e-Commerce companies called Shopee. Shopee is a company that is under the auspices of the SEA Group. Indonesian Shopee was officially introduced on 12 December 2015 under the auspices of PT Shopee Internasional Indonesia, located at Wisma 77 Tower 2, Street Letjen Jakarta. This study aims to analyze the influence of fashion lifestyles, sales promotions, and self-image on impulse buying behavior and customer satisfaction. In people's lives sales promotion is one of the factors considered in making a purchase without planning beforehand. Sales promotion is a marketing effort to encourage prospective buyers to buy more and more often [2].

\section{LITERATURE REVIEW}

\subsection{Lifestyle}

Lifestyle is a pattern of one's life that is expressed in activities, interests and income [3]. Lifesytle refer to a pattern of comsumption reflecting a person,s choices of how he or she spend time and money [4]. lifestyle is a description of behavior, patterns and ways of life that are shown how activities and interests they think about themselves so that they differentiate between others and the environment through the social symbols they have.

Shopee is one of eCommerce which can be said to have a fairly rapid development in this modern era, similar business competition is characterized by the number of emerging eCommerce types, for which business owners are required to know the desires and needs of consumers in order to maintain customer loyalty. 
This study explores the influence of fashion lifestyle variables on impulse buying behavior and customer satisfaction, using shopping lifestyle indicators proposed by [5] :

1. Respond to buying every ad offer regarding fashion products

2. Buy the latest clothes when you see them

3. Shop for the most famous brands

4. Convinced that the famous brand is best in terms of quality

5. Fun activities

Hypothesis 1 : Fashion lifestyle has a significant effect on impulse buying behavior

The higher the fashion lifestyle of a consumer, the higher the level of consumer impulse buying behavior.

Hypothesis 2 : Fashion lifestyle has a significant effect on customer satisfaction

The higher the consumer fashion lifestyle, the higher the level of satisfaction the consumer has with the clothes worn.

\subsection{Sales Promotion}

Sales promotion is related to short-term incentives to encourage the purchase or sale of a product or service [6]. These incentives are related to rewards, whether they are related to refunds in the form of discounts, guarantees or can be in the form of product samples and so on. Sales promotion is a marketing effort to encourage prospective buyers to buy more and more often [2]. According to Kotler translated by Alma The purpose of sales promotion is to attract new buyers, give gifts or rewards to old customers, increase the repurchase power of old consumers, prevent consumers from running to other products, populate brands or increase loyalty, increase short-term sales volume in order to expand long-term "market share" [7]

This study examines sales promotion variables on impulse buying behavior through indicators of sales promotion:

Promotion time is the value or number of sales promotions carried out by the company and compliance or suitability of promotional goals [8]. Discounts, shopping coupons, and frequent shopper programs [9].

Hypothesis 3 : Sales promotion has a significant effect on impulse buying behavior

The more like the sales promotion given to consumers, the higher the level of consumer impulse buyer's behavior.

Hypothesis 4 : sales promotion has a significant effect on customer satisfaction

The more sales promotions given to consumers, the higher the customer satisfaction will be.

\subsection{Self Image}

Self-image refers to one's views or understanding of himself [10]. Self-image is someone's view of himself or how someone describes himself [11]. This study uses indicators of self-image proposed by [12]: Have a strong self-confidence. Able to control themselves, Oriented to ambitions and goals.

Hypothesis 5: self-image has a significant effect on impulse buying behavior

The higher the self-image of a consumer, the higher the level of consumer impulse buying behavior. This is further strengthened by opinion [13] which states that improving self-image is a person's psychological motivation in behaving impulse buying.

Hypothesis 6: Self-image has a significant effect on customer satisfaction

The higher the self image of a consumer, the higher the level of customer satisfaction with the clothes worn. This has been strengthened by opinions [14] which states that self-image not only increases consumer satisfaction but also consumer relationships with brands.

\subsection{Impulse Buying Behavior}

Impulsive buying is a purchase that occurs when someone sees an item and suddenly wants to buy the item, and then decides to make a purchase right away [15]. Impulsive buying is an act of buying that is done without having a previous plan formed before entering the store [16]. The types of impulse buying according to [17] namely: Impressive buying reminder, pure impulsive buying, suggested impulsive buying, planned impulsive buying. This study uses indicators of impulse buying behavior proposed by [18] : Unplanned purchases, Purchases without thinking as a result, Purchases are influenced by emotional states, Purchases are influenced by attractive offers.

Hypothesis 7: Impulse Purchasing Behavior has a significant effect on customer satisfaction The higher the consumer impulse buying behavior, the higher the level of satisfaction that consumers feel after buying these clothes. 


\subsection{Customer Satisfaction}

customer satisfaction is a feeling of pleasure or disappointment a person who appears after comparing the performance of products that are thought of the expected performance [1]. Consumer satisfaction is the result felt by buyers who experience the performance of a company that fits their expectations [19]. This study uses indicators of customer satisfaction according to [20] : Confirmation of expectation, Repurchase interest. And according to [21] : No complaints about the product, customer satisfaction in the whole product.

\subsection{Research Framework}

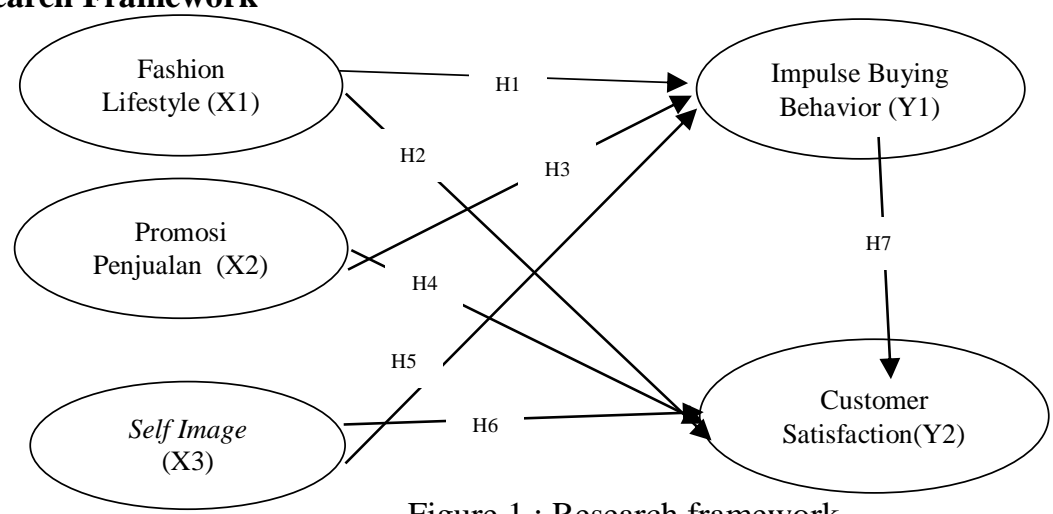

Figure 1 : Research framework

\section{METHODOLOGY}

Research uses a quantitative approach is a method based on the philosophy of positivism, used to examine the population or a particular sample, data collection using research instruments, data analysis is quantitative / statistical, with the aim of testing what has been set [12] This research variable consisted of independent variables Fashion lifestyle, sales promotion and self image. Intervening variable Impulse buying behavior. And the variable is bound to Customer satisfaction. The population in this study were students who used the Shopee application at Narotama University Surabaya, as many as 100 respondents. The data analysis technique uses Partial Least Square (PLS) with SmartPLS 3 software.

\section{RESULT AND DISCUSSION}

The R-Adjusted impulse buying behavior variable was 0.736 or $73.6 \%$. The results showed that the independent variables of fashion lifestyle, sales promotion, and self-image contributed $73.6 \%$ to impulse buying behavior and the remaining $26.4 \%$ was influenced by other factors, while for customer satisfaction variables R-Adjusted is 0.836 or $83.6 \%$. This result shows that the independent variables of fashion lifestyle, sales promotion and self-image contribute $83.6 \%$ and the remaining $16.4 \%$ is influenced by other factors.

In testing the hypothesis, a data must fulfill a criterion, and the hypothesis is said to be accepted if the tstatistic value is greater than $\mathrm{t}$-table and if the $\mathrm{p}$-value is less than 0.05 and vice versa.

The output of the Smart PLS is as follows:

Tabel 1 : Path Coefficient

\begin{tabular}{|l|c|c|}
\hline \multicolumn{1}{|c|}{ Path Coefficient } & t-statistic & $\boldsymbol{p}$-value \\
\hline Fashion Lifestyle $\rightarrow$ Impulse buying Behaviour & 2.747 & 0.003 \\
\hline Fashion Lifestyle $\rightarrow$ Customer Satisfaction & 3.862 & 0.000 \\
\hline Sales Promotion $\rightarrow$ Impulse Buying Behaviour & 3.084 & 0.001 \\
\hline Sales Promotion $\rightarrow$ Customer Satisfaction & 1.840 & 0.033 \\
\hline Self Image $\rightarrow$ Impulse Buying Behaviour & 2.986 & 0.001 \\
\hline Self Image $\rightarrow$ Customer Satisfaction & 2.955 & 0.002 \\
\hline Impulse Buying Behaviour $\rightarrow$ Customer Satisfaction & 1.902 & 0.029 \\
\hline
\end{tabular}




\begin{tabular}{|l|c|c|}
\hline $\begin{array}{l}\text { Fashion Lifestyle } \rightarrow \text { Impulse Buying Behaviour } \rightarrow \text { Customer } \\
\text { Satisfaction }\end{array}$ & 1.773 & 0.038 \\
\hline $\begin{array}{l}\text { Sales Promotion } \rightarrow \text { Impulse Buying Behaviour } \rightarrow \text { Customer } \\
\text { Satisfaction }\end{array}$ & 1.528 & 0.064 \\
\hline $\begin{array}{l}\text { Self Image } \rightarrow \text { Impulse Buying Behaviour } \rightarrow \text { Customer } \\
\text { Satisfaction }\end{array}$ & 1.528 & 0.064 \\
\hline
\end{tabular}

Source, output SmartPLS 3.0, 2019

\subsection{Direct influence \\ Hypothesis 1: Effects of lifestyle fashion on impulse buying behavior}

Based on the results of the analysis, it can be seen that lifestyle fashion has a positive and significant effect on impulse buying behavior with the results of p-value $0.003<0.050$ and t-staistic value $>t$-table which is $2.747>1.661$.

The results of this study are supported by previous research carried out [22] which states that shopping lifestyle has a significant effect on impulse buying behavior. This shows that consumers who have a high fashion lifestyle will buy clothes at shopee that are in accordance with themselves and influenced by emotional conditions and attractive offers without prior planning. Because with the higher fashion lifestyle of consumers (students), the higher the impulse buying behavior.

Hypothesis 2: Effects of fashion lifestyle on customer satisfaction

Based on the results of the analysis, it can be seen that lifestyle fashion has a positive and significant effect on customer satisfaction with the results of p-value $0.000<0.050$ and t-staistik $>\mathrm{t}$-table which is $3.862>1.661$

This research was supported by research conducted by [23] shows that lifestyle has a positive effect on customer satisfaction, this shows that every lifestyle improvement will be followed by an increase in customer satisfaction. This shows that consumers who have a high-wear lifestyle will buy clothes that are considered to be in accordance with themselves and their expectations. The higher the lifestyle of dressing someone (student), the higher the level of satisfaction of the customer (student) for the clothes that have been purchased or worn.

Hypothesis 3 : Effects sales promotion on impulse buying behaviour

Based on the results of the analysis, it can be seen that sales promotion has a positive and significant effect on impulse buying behavior with the results of $\mathrm{p}$-value $0.001<0.050$ and $\mathrm{t}$-staistik $>\mathrm{t}$-table which is 3.084> 1.661 .

This research was supported by previous research conducted by [24] which states that sales promotions have a positive and significant effect partially on impulse buying. This shows that with the promotion provided by Shopee to customers it will affect consumers to make purchases without prior planning because the more sales promotions that are given to consumers (students), the more impulsive buying behavior of these students.

Hypothesis 4 : Effects Sales Promotion on customer satisfaction

Based on the results of the analysis it can be seen that sales promotion has a positive and significant effect on customer satisfaction with the results of p-value $0.033<0.050$ and t-staistik $>\mathrm{t}$-table which is $1,840>$ 1,661 .

The purpose of sales promotions is to attract new consumers and increase satisfaction for old consumers [7]. This shows that consumers will buy clothes at shopee when the promotions offered are in accordance with their needs and as expected because, the more sales promotions given to consumers (students), the more the level of customer satisfaction (students) will be clothes that have been bought or worn.

Hypothesis 5 : Effects self image on impulse buying behaviour

Based on the results of the analysis it can be seen that self image has a positive and significant effect on impulse buying behavior with the results of $\mathrm{p}$-value $0.001<0.050$ and $\mathrm{t}$-staistik $>\mathrm{t}$-table which is $2.986>$ 1.661 .

This research was supported by previous research conducted by [13] said that increasing self image is a person's psychological motivation in behaving impulsive buying. This shows that consumers who have a high self-image are more likely to dress according to themselves because of what is seen and considered to be in accordance with themselves so consumers will decide on unplanned purchases beforehand.

Hypothesis 6 : Effect of self image on customer satisfaction

Based on the results of the analysis, it can be seen that self image has a positive and significant effect on customer satisfaction with the results of p-value $0.033<0.002$ and t-staistik $>\mathrm{t}$-table which is $2.955>$ 1.661 . 
This research was supported by previous research conducted by [14] The results show that self-image not only increases consumer satisfaction but also consumer-brand relationships. This shows that consumers who have strong self-confidence will buy clothes that suit themselves and their hopes, because the higher the self-image, the higher the level of customer satisfaction with clothing that has been purchased or worn.

Hypothesis 7 : Effect impulse buying behaviour on customer satisfaction

Berdasarkan hasil dari analisis dapat diketahui bahwa impulse buying behaviour berpengaruh positif dan signifikan terhadap customer satisfaction dengan hasil dari $p$-value $0.029<0.050$ dan $\mathrm{t}$-staistik $>\mathrm{t}$-table yaitu $1.902>1.661$.

The results show that self-image not only increases consumer satisfaction but also consumer-brand relationships. This shows that consumers who have strong self-confidence will buy clothes that suit themselves and their hopes, because the higher the self-image, the higher the level of customer satisfaction with clothing that has been purchased or worn.

\subsection{Indirect Effects}

\section{Fashion Lifestyle for Customer Satisfaction Through Impulse Buying Behavior}

The results of this study indicate that the lifestyle of fashion has a positive and significant influence indirectly through impulse buying behavior. This is because the p-value is $0.038<0.050$ and t-statistics $>$ t-table $1,773>1,661$.

This shows that consumers who have high-dressed lifestyles will buy clothes that are in accordance with their hopes and desires.

\subsection{Sales Promotion for Customer Satisfaction Through Impulse Buying Behavior}

The results of this study indicate that sales promotions have a positive and insignificant influence on customer satisfaction through impulse buying behavior. This is because of p-value $0.064>0.050$ and $t-$ statistics $<$ t-table $1.528<1.661$.

This shows that customers intend to repurchase clothing even though there is no price discount because customers are more likely to buy clothes according to expectations, needs and time that are considered most appropriate.

\subsection{Self Image of Customer Satisfaction Through Impulse Buying Behavior}

The results of this study indicate that self image has a positive and significant effect indirectly through impulse buying behavior. This is because the value of p-value $0.043<0.050$ and t-statistics $>$ t-table $2.719>1,661$

This shows that consumers with a high self-image tend to buy clothes that are suitable for themselves and are influenced by the emotional state purchased in accordance with their expectations.

\section{CONCLUSION}

\subsection{Conclusion}

The findings of this study indicate that the direct influence of independent variables on lifestyle fashion, sales promotion, and self-image has a significant influence on inpulsive buying behavior and customer satisfaction in students who use the Shopee application at Narotama University Surabaya. Respondents stated that they agreed to the dressing lifestyle, sales promotion and self-image. this, shows that consumers who have a high lifestyle and self-image will tend to buy clothes according to their expectations when there are promotions or no promotions.

For fashion lifestyle variables and self-image has a positive and significant indirect effect on customer satisfaction through impulse buying behavior, while sales promotion has a positive and not significant indirect effect on customer satisfaction through impulse buying behavior. This shows that customers intend to repurchase clothing even though there is no price discount because customers are more likely to buy clothes according to expectations, needs and time that are considered most appropriate.

\subsection{Limitations}

The limitations of the results of this study are: the validity of the results of this study cannot be generalized because the data of this study are only sourced from one industry, as well as measurements of impulsive purchasing variables and customer satisfaction with independent variables of dressing lifestyle, sales promotion, and self image. Subsequent research can be directed by expanding the population and 
samples and increasing the scope of the company in the same field, so that it can add empirical validity, and further research may further explore the roles of other independent variables on impulsive buying behavior and customer satisfaction in the online shop.

\section{REFERENCES}

[1] Kotler dan Keller, Manajemen Pemasaran. Jilid I., Ke 13. Jakarta: Erlangga, 2009.

[2] J. \& R. M. Cummins, Sales Promotion. Jakarta: PPM, 2004.

[3] G. Kotler,Philip \& Amstrong, Prinsip-prinsip Pemasaran Jilid 1, 12th ed. Erlangga, 2008.

[4] U. Sumarwan, Perilaku Konsumen: Teori dan Penerapan Dalam Pemasaran. Bogor Selatan: Ghalia Indonesia, 2004.

[5] Cobb J.C. \& Hoyer W.D., "Planned Versus Impulse Purchase Behaviour," J. Retail., vol. 64, no. 4, 1986.

[6] G. Kotler,Philip \& Amstrong, Dasar-dasar Pemasaran Principle of Marketing 7e Jilid 2, Bahasa Ind. Jakarta: Prenhallindo, Jakar, 1997.

[7] B. Alma, Manajemen Pemasaran dan Pemasarn Jasa. Bandung: Alfabeta, 2009.

[8] P. \& K. L. K. Kotler, Marketing Management. Northwestern University, New Jersey: Prentice Hall International, 2006.

[9] C. W. Utami, Manajemen Ritel : Strategi dan Implementasi Operational Bisnis Ritel MOdern di Indonesia. Jakarta: Salemba Empat, 2010.

[10] Mappiare, Pengantar Konseling dan Psikoterapi. Jakarta: Rajawali Pers, 2010.

[11] Hery Wibowo, Fortune Favors The Ready: Keberuntungan Berpihak kepada Orang-orang yang Siap. Bandung: OASE Mata Air Makna, 2017.

[12] Fleet, Mengenali dan Mengembangkan Kekuatan Tersembunyi di Dalam Diri. Jakarta: Spektrum, 2001.

[13] A. Indarjati, "Sekilas Tentang Impulsive Buying," Psikodimensia. Semarang Fak. Psikol. Univ. Katolik Soegijapranata, vol. Vol.4, no. No.1, p. (1-8), 2003.

[14] S. Park, "Congruence between Brand Personality and Self-Image, and the Mediating Roles of Satisfaction and Consumer-Brand Relationship on Brand Loyalty," Asia Pacific Adv. Consum. Res., 2005.

[15] M. J. Arnold and K. E. Reynolds, "Hedonic shopping motivations," J. Retail., 2003.

[16] J. \& M. M. C. Mowen, Perilaku Konsumen. Jakarta: Erlangga, 2002.

[17] S. et. A. Hawkins, Consumer Behaviour Building Marketing Strategy, Series In. New York: McGraw-Hill Book Company, 2004.

[18] S. Bong, "Pengaruh In-Store Stimuli Terhadap Impulse Buying Behaviour Konsumen Hypermart Di Jakarta," Ultim. Manag., vol. 3, no. 1, pp. 31-52, 2011.

[19] P. Kotler, Manajemen Pemasaran : Analisis Perencanaan Implementasi dan Pengendalian Jilid II. Jakarta: Prenhallindo, Jakar, 2000.

[20] F. Tjiptono, Pemasaran Jasa. Malang: Bayumedia Publishing, 2005.

[21] D. I. Pratiwi, ““"Analisis Pengaruh Harapan Pelanggan, Kualitas Produk, dan Kepuasan Pelanggan Terhadap Loyalitas Pelanggan Internet Flash Unlimited di Semarang,” 2010.

[22] E. Japarianto, "PENGARUH SHOPPING LIFE STYLE DAN FASHION INVOLVEMENT TERHADAP IMPULSE BUYING BEHAVIOR MASYARAKAT HIGH INCOME SURABAYA," 2009.

[23] Muchsin, "Pengaruh Gaya Hidup terhadap Kepuasan Konsumen Kosmetik Elizabeth Hellen di Kecamatan Dewantara Kabupaten Aceh Utara," vol. 6, pp. 85-89, 2017.

[24] D. Amanah and S. P. Pelawi, "Jurnal Quanomic Vol. III No. 02 - Oktober 2015 | ISSN No. 23392037," vol. III, no. 02, pp. 10-18, 2015. 